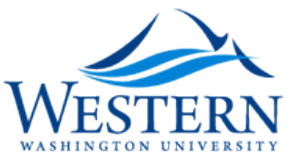

Western Washington University

Western CEDAR

$5-1984$

\title{
Austro-German Liberalism and the Modern Liberal Tradition
}

Harry Ritter

Western Washington University, harry.ritter@wwu.edu

Follow this and additional works at: https:// cedar.wwu.edu/history_facpubs

Part of the European History Commons

\section{Recommended Citation}

Ritter, Harry, "Austro-German Liberalism and the Modern Liberal Tradition" (1984). History Faculty and Staff Publications. 31. https://cedar.wwu.edu/history_facpubs/31

This Article is brought to you for free and open access by the History at Western CEDAR. It has been accepted for inclusion in History Faculty and Staff Publications by an authorized administrator of Western CEDAR. For more information, please contact westerncedar@wwu.edu. 


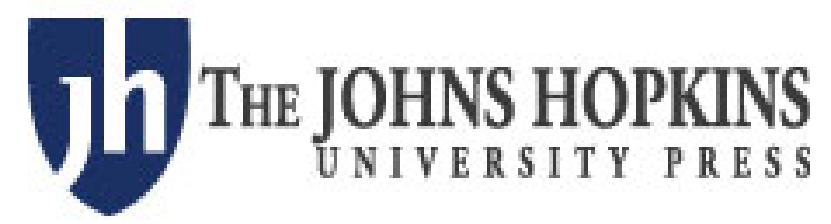

\author{
German Studies Association
}

Austro-German Liberalism and the Modern Liberal Tradition

Author(s): Harry Ritter

Source: German Studies Review, Vol. 7, No. 2 (May, 1984), pp. 227-248

Published by: The Johns Hopkins University Press on behalf of the German Studies Association

Stable URL: http://www.jstor.org/stable/1428571

Accessed: 29/10/2014 13:40

Your use of the JSTOR archive indicates your acceptance of the Terms \& Conditions of Use, available at http://www.jstor.org/page/info/about/policies/terms.jsp

JSTOR is a not-for-profit service that helps scholars, researchers, and students discover, use, and build upon a wide range of content in a trusted digital archive. We use information technology and tools to increase productivity and facilitate new forms of scholarship. For more information about JSTOR, please contact support@jstor.org. 


\title{
Austro-German Liberalism and the Modern Liberal Tradition
}

\author{
Harry Ritter \\ Western Washington University
}

Der Liberalismus ist aus, eine neue Zeit bricht an, Platz für uns!

$$
\text { Hermann Bahr, } 1882
$$

Die Welt will heute vom Liberalismus nichts mehr wissen. Ausserhalb Englands ist die Bezeichnung 'Liberalismus' geradezu geächtet.

Ludwig von Mises, 1927

Modes of historical interpretation change ... the past grows with the present. Historians view past and present in some sort of simultaneous vision. Some of them believe that an informed picture of the past may shed some light on the unfolding future - or at least they know that a mythical past ill instructs the present.

Fritz Stern, The Failure of Illiberalism

In a widely-cited essay on turn-of-the century Vienna, Carl Schorske alludes to the"dissolution of the classical liberal view of man in the crucible of Austria's modern politics. ... [and] the emergence of psychological man from the wreckage of the old culture."1 The theme of liberal decline has provided Schorske with the backdrop for several important articles on late nineteenthcentury Austria, and a number of interesting monographs on

1. Carl E. Schorske, "Politics and the Psyche in fin de siècle Vienna: Schnitzler and Hofmannsthal," The American Historical Review, 66 (July 1961): 946. 
related topics have also recently appeared. ${ }^{2}$ Relatively few historical studies, however, address the subject of Austrian liberalism per se, ${ }^{3}$ and those which do are mostly broad surveys. ${ }^{4}$

2. Schorske's essays are collected in Fin-de-Siècle Vienna: Politics and Culture (New York, 1980). Related works include William J. McGrath, Dionysian Art and Populist Politics in Austria (New Haven, Conn., 1974); Andrew G. Whiteside, The Socialism of Fools: Georg Ritter von Schönerer and Austrian Pan-Germanism (Berkeley, 1975); and John W. Boyer, Political Radicalism in Late Imperial Vienna: Origins of the Christian Social Movement, 1848-1897 (Chicago, 1981).

3. Even native Austrian historians have paid scant attention to the subject for its own sake. This is partially explained by the fact that, from the late nineteenth century to the 1950s, the philosophical faculties of Austrian universities were often hostile to liberalism, and the leading early historians of the movement - e.g., Friedjung, Kolmer, Charmatz - worked primarily as journalists and freelance authors. The fact that Richard Charmatz, once called by Fritz Fellner the "real historian of Austrian liberalism" ("Richard Charmatz: Biograph Österreichs," Forum [March 1965]: 113-114), is usually either forgotten completely or dismissed as a mere "publicist" is just one measure of the extent to which the subject has been deemed insignificant. To be sure, histories of nineteenth-century Austria customarily concede that certain ministers (Bruck, Koerber, Böhm-Bawerk, etc.) were strongly influenced by liberal ideas, that rentiers and the banking, commercial, and manufacturing community were sympathetic to liberalism, and that the press - above all, the Neue Freie Presse and the Neues Wiener Tagblatt was a liberal influence. But, having mentioned this in passing, Austrian historians normally proceed to what they regard as the genuinely important topics: nationalism, socialism, constitutional reform, the role of the Jews, etc.

4. Among the indispensable works: Richard Charmatz, DeutschÖsterreichische Politik: Studien über den Liberalismus und über die auswärtige Politik Österreichs (Leipzig, 1907), by an early twentieth century proponent of "neoliberal" regeneration who laid bare the flaws of the "old liberalism" in classic fashion - still the "best account of the development of the 'liberal' party groupings and factions of the Reichsrat" (Karl Vocelka, Verfassung oder Konkordat? Der publizistische und politische Kampf der österreichischen Liberalen um die Religionsgesetze des Jahres 1868 [Vienna, 1978], p. 16); Georg Franz, Liberalismus: die deutschliberale Bewegung in der habsburgischen Monarchie (Munich, 1955), sympathetic to the liberals, but vitiated by the tone of self-pity and "tragedy" characteristic of national liberalism in the tradition of classic liberal historiography á la Friedjung, as well as antipathy to the alleged atomistic individualism of western Europe; Karl Eder, Der Liberalismus in Altösterreich: Geisteshaltung, Politik, Kultur (Vienna, 1955), written by a priest, unsympathetic to liberalism; Albert Fuchs, Geistige Strömungen in Osterreich 1867-1918 (Vienna, 1949), written with engaging naiveté and humanity, though Fuchs was a Marxist with a compulsion to interpret absolutely everything in simplistic terms of class-bound ideology; Eduard Winter, Romantismus, Restauration, und Frühliberalismus im österreichischen Vormärz (Vienna, 1968) and Revolution, Neoabsolutismus und Liberalismus in der Donaumonarchie (Vienna, 1969), couched in the mock epic tone of an "ordeal" of liberal Catholicism in the Vormärz, with the philosopher Bolzano as martyr. Like the surveys of Franz, Eder, and Fuchs, Winter's books are primarily studies in traditional Geistesgeschichte. Diethild Harrington-Müller, Der Fortschrittsklub im Abgeordnetenhaus des österreichischen Reichsrat 1873-1910 (Vienna, 1972), surveys 
Aside from these general studies, our detailed knowledge of the subject - such as it is - rests on scattered articles, chapters or segments of chapters in general histories and monographs, and a handful of Austrian disserations. ${ }^{5}$

In this essay I propose to broadly evaluate the existing literature on Austrian liberalism, and to advocate, as well, some new directions for research; in the process I will frequently address the question of current scholarship on liberalism in general, and occasionally touch on the situation with regard to regions other than Austria, particularly Germany and Britain. My remarks will deal more with ways historians have thought about liberalism and might think about liberalism than with liberalism itself. It is no doubt preferable, as someone has said, to supply one concrete answer than a host of proposals for further research; the fact remains that the important subject of Austro-German liberalism has hitherto been on the periphery of historians' research agenda. In this case, a reconsideration of conventional generalizations would seem to repay the effort.

It is not difficult to see why the subject of liberalism in Austria has been neglected. It is a fact, after all, that proponents of liberalism in Austria never succeeded in defining their aims in a

the history of the liberal party coalitions in the Cisleithanian parliament. The scholarly and popular essays of Adam Wandruszka must also be noted, especially "Österreichs politische Struktur," in Heinrich Benedikt, ed., Geschichte der Republik Österreich (Vienna, 1954). Wandruszka has been very important for establishing a widely-accepted sense of liberalism's place in the sweep of modern Austrian political history. His conception of a dialectical conflict between liberalism and its "post-liberal" antitheses - nationalism, socialism, and Christian socialism has been so thoroughly assimilated over the past twenty-five years that his work is often no longer specifically cited. His essay on "Österreichs politische Struktur" is an impressive synthesis - possibly the key source in the contemporary network of literature about modern Austrian politics - but too many historians have accepted it uncritically as the final word on liberalism.

5. It should be said that a number of recent monographs which focus on subjects other than liberalism contain much valuable information on liberalism itself - e.g., Heinrich Lutz, Österreich-Ungarn und die Gründung des deutschen Reiches. Europäische Entscheidungen 1867-1871 (Frankfurt, 1978), and HarmHinrich Brandt, Der Österreichische Neoabsolutismus. Staatsfinanzen und Politik 1848-1860, 2 vols. (Göttingen, 1978). This scattered information needs to be gathered and synthesized. One should also note the appearance of two important articles on the conceptual history of liberalism in Rudolf Vierhaus, "Liberalismus" and Rudolf Walther, "Exkurs: Wirtschaftlicher Liberalismus," in Otto Brunner, Werner Conze, and Reinhart Koselleck, eds., Geschichtliche Grundbegriffe. Historisches Lexikon zur politisch-sozialen Sprache in Deutschland (Stuttgart, 1982), vol. 3: pp. 741-785, 787-815. 
way which appealed to the broad public, ${ }^{6}$ and that organized liberalism enjoyed only a fleeting taste of parliamentary leadership - based on a severely limited franchise - in the 1860s and 1870s. On these grounds alone, it is perhaps not surprising that Austrian liberalism should often be overlooked, or dismissed as a historical curio and political dead end. Moreover, for obvious reasons the focus of attention in central European studies in recent years has been on National Socialism and its origins in late nineteenthcentury radicalism and "cultural pessimism"; there has been little incentive for either senior or apprentice historians to study a movement such as liberalism, whose values are widely alleged to have been overwhelmed and transcended in the early twentieth century. John W. Boyer's new study of Viennese Christian Socialism, cited above, deals extensively with liberalism and constitutes in some respects an important advance over previous literature, insofar as it takes seriously some of liberalism's positive achievements. Still, even here liberalism is not given center stage, but functions as a foil for "radicalism."

In German history the situation is now improving (see note 17), although until quite recently interest in liberalism was chiefly peripheral, largely confined to charting the reasons for the doctrine's inability to arrest aggressive nationalism, imperialism, political irrationalism, and totalitarianism. ${ }^{7}$ Indeed, the entire

6. Franz, Liberalismus, p. 239, speaks of the liberals' "theoretical confusion" and striking "lack of political effectiveness." A standard reason given for neglecting the subject is that organized political liberalism never progressed beyond the level of an individualistic Honoratiorenpartei to produce a disciplined "mass party" (e.g., Vocelka, Verfassung oder Konkordat?, p. 94). If one's focus is primarily on the evolution and success of political parties, it is likely that the nineteenth-century liberal movement - identified with the Verfassungspartei and its fragmented successors - will be interesting, at best, only as a precursor of subsequent developments. Here again, Wandruszka's work has been crucial in establishing the broad frame of reference, even for those not narrowly concerned with party or political history such as Schorske.

7. See, e.g., most of the essays in Karl Holl and Günter List, eds., Liberalismus und imperialistischer Staat: Der Imperialismus als Problem liberaler Parteien in Deutschland 1890-1914 (Göttingen, 1975). An exception is Hans-Günter Zmarzlik's "Das Kaiserreich als Einbahstrasse?" pp. 62-71. Not infrequently liberalism is itself made to bear a heavy burden of guilt for the rise of twentieth-century tyranny - and it is not the Marxists alone who tar liberalism with the brush of embryonic "fascism." For an interpretation strongly influenced by East German scholarship see Walter Struve, Elites Against Democracy: Leadership Ideals in Bourgeois Political Thought in Germany, 1890-1933 (Princeton, 1973); a recent non-Marxist example is James J. Sheehan, German Liberalism in the Nineteenth Century (Chicago, 1978), pp. 273, 276-278, 281-282. There is wide agreement on German 
intellectual climate in recent decades has been fundamentally unfavorable to the study of liberalism - whether it be the Austrian species, the American, or any other variety - simply because the notion that liberalism "died" on the eve of World War I and the idea that its values are "bankrupt" today have become so remarkably widespread and uncritically accepted. In many quarters, liberalism is now automatically handled with heavy irony as yet another idea whose time has come and gone, one whose nineteenth-century disciples were either cynical, self-serving hypocrites or, at best, confused captives of their own pathetic illusions. ${ }^{8}$

And yet, when we shift our eyes away from the printed page, the contemporary political and economic scene in western Europe and North America testifies at least as much to the liberal tradition's vigor as to its decline. Even in the greater part of central Europe, a neo-liberal order flourishes today (partially masquerading, to be sure, under the name of "social democracy"). We must certainly recognize that the establishment of the present order was indirectly facilitated by Hitler, who destroyed powerful, traditional obstacles to liberalism; that it was introduced under the eye of western occupation; and that it was rendered especially attractive to the native population by the shadow of Soviet tyranny. Still, the fact that it not only exists, but apparently flourishes and expands, suggests that it is not merely the product of coercion or expediency, and that native traditions may somehow be involved. I would like to suggest - while recognizing that theories of liberal as well as illiberal Kontiniutätslinien in central European history run

liberalism's "failure." Sheehan, for example, cites "liberalism's larger failure to shape German politics and society" (p. 177), while Ralf Dahrendorf's widely criticized but nonetheless influential Society and Democracy in Germany (New York, 1967) is a bout "Germany's persistent failure to give a home to democracy in its liberal sense" (p. 14).

8. Christopher Lasch's cavalier approach in The Culture of Narcissism: American Life in an Age of Diminishing Expectations (New York, 1978), p. xii, is fairly typical: "Liberalism, the political theory of the ascendant bourgeoisie, long ago lost the capacity to explain events in the world of the welfare state and the multinational corporation; nothing has taken its place. Politically bankrupt, liberalism is intellectually bankrupt as well." Lasch makes the common but erroneous assumption that liberalism should be narrowly equated with laissez-faire capitalism. It would not be difficult to compile a long list of quotations written in the same sardonic vein; for a sampling of earlier opinion see Max Savelle, "Is Liberalism Dead?" in the author's Is Liberalism Dead? and Other Essays (Seattle, 1967), pp. 3-22. On the identification of the term "liberalism" with free enterprise economics, a surprisingly recent practice which dates only from the turn of the twentieth century, see Walther, "Exkurs: Wirtschaftlicher Liberalismus," pp. 787, 808-811. 
the risk of being equally one-sided, anachronistic, and misleading ${ }^{9}$ - that the subject of German liberalism in nineteenth-century Austria deserves more sympathetic attention than it has hitherto received.

The logical place to begin is with a survey of the broad contours of the historiographical field as it stands today. At the most basic level, conventional wisdom casts the history of Austrian liberalism as a tale of failure. Liberalism was "the one political force ... that perpetually lost." 10 This general story is typically emplotted (deliberately or not) in a number of ways, individually or in various combinations: ${ }^{11}$ more or less sympathetically, as nostalgic elegy, poignant melodrama, or melancholy pseudo-tragedy; with olympian (often Hegelian) detachment, as a result of a transcendental, inexorable process of change and dissolution; or self-righteously and satirically - often with a touch of Schadenfreude - as a grotesque comedy or farce of "internal contradictions," dialectical oppositions, and paradoxes.

These remarks generally apply to the emplotment of central European liberalism as a whole. Several decades ago, when the ideals of classical liberalism were taken seriously and the individual will was still given generous credit as a force in human affairs, bourgeois tragedy - often coupled with the theme of "missed opportunities" - was a popular plot form. In this literature, a combination of factors - dynastic tradition, ecclesiastical obscurantism, aristocratic Engherzigkeit, the mistakes and flaws of the liberal leaders - led to liberalism's "tragic" failure. The message concerning the "fate" of liberalism was typically conveyed through the story of the martyrdom of a few far-sighted but isolated heroes - in Austria's case, figures such as Admiral Tegetthoff, Adolf Fischhof, to a certain degree Schmerling

9. Richard J. Evans, "Liberalism and Society: The Feminist Movement and Social Change," in Richard J. Evans, ed., Society and Politics in Wilhelmine Germany (New York, 1978), p. 204.

10. Fritz Stern, The Politics of Cultural Despair (Garden City, N.Y., 1965), p. 2. Stern is speaking here of northern Germany, but his comment applies, with qualifications, to the historiography of Austrian liberalism as well. The story of liberalism is usually emplotted in much the same way as the larger history of the Danubian monarchy itself. Ideas of what was possible for nineteenth-century Austrian liberalism are colored by conventional ideas about what was possible for the old empire. If we believe that the empire was "destined" to collapse, this is likely to affect our approach to liberalism and its "fate."

11. On the idea of historiographical "emplotment," see Hayden White, Metahistory: The Historical Imagination in Nineteenth-Century Europe (Baltimore, 1973). 
and, above all, Freiherr von Bruck. ${ }^{12}$ More recently, the influence of political sociology and social psychology has produced interpretations which put less stress on individual choices or character flaws, and lay more emphasis on impersonal, long-term environmental and sociopsychological barriers to the success of liberalism. This results in predominantly satiric emplotments of the story of central Europe's "long road to modernity" in which there are few heroes or martyrs. In the context of the "hard realities of German life,"13 liberalism in central Europe is presented as a political fantasy which had no chance for success and little practical relationship to the world in which it worked. Here the mood is best described as one of ironic satire, only occasionally relieved by a note of mild pity.

Whatever the overall plot form, convention usually demands that the Austrian story be divided (explicitly or tacitly) into a threestage scheme of periodization: 1) "early" liberalism (Frühliberalismus) - youthful, naive, strongly conditioned by the humanitarian ideas of the Aufklärung and Josephinism - which dissolves overnight in the sobering revolutionary upheavals of 1848 . (Three specific varieties of early liberalism are normally identified, each with different socioeconomic roots: Hofratsliberalismus, ständisch-aristokratischer Liberalismus, and bürgerlichdemokratischer Liberalismus.)14 2) "High" liberalism (Hochliberalismus) - prosaic, materialistic, hypocritical, frightened of democracy and insensitive to social reform - which collapses on the federal level in 1879, with the advent of Taaffe, and on the municipal level in the 1890s, with the electoral triumphs of Christian Socialism. (A subordinate theme here concerns the continuing strain of bureaucratic liberalism, or Hofratsliberalismus, an extension of the eighteenth-century notion of the Polizeistaat based on law, though this is often distinguished from liberalism proper under the rubric "Josephinism.") 3) "Late" or "post" liberalism (Spätliberalismus) - politically sterile and senescent, though characterized by the seductive sheen of a third generation cultural afterglow. Following this illusory Indian summer of Kulturliberalismus, liberalism "dies" sometime before 1914, largely unnoticed and unmourned.

12. See, for example, Heinrich Friedjung's Der Kampf um die Vorherrschaft in Deutschland, 2 vols. (Stuttgart/Berlin, 1897), as well as his Österreich von 1848 bis 1860, 2 vols. (Stuttgart/Berlin, 1908-1912); also, Richard Charmatz, Adolf Fischhof (Stuttgart/Berlin, 1910) and Minister Freiherr von Bruck (Leipzig, 1916).

13. Sheehan, German Liberalism, p. 187.

14. Vocelka, Verfassung oder Konkordat?, p. 15. 
This interpretive paradigm rests, in turn, on broad theoretical underpinnings provided by a few key studies: e.g., Adam Wandruszka's classic analysis of modern Austria's "political structure," according to which liberalism was aufgehoben in dialectical conflict with its own offspring - Pan-Germanism, Socialism, and Christian Socialism - and Hans Rosenberg's analysis of central Europe's late nineteenth-century "great depression," which undermined the materialistic ethos of the Gründerzeit and its wagendes Bürgertum. ${ }^{15}$ It is reinforced, as well, by generations of serious and popular literary history, aesthetic criticism, and Kulturgeschichte which concentrate on Vienna's "fröliche Apokalypse" and the literature of "fin-desiècle" alienation as the most significant cultural legacy of the late Austrian empire.

This is obviously a simplified overview but not, I think, an unfair or inaccurate one. I do not suggest that previous orientations are completely false; what we have at present is a very full catalog of the weaknesses and deficiencies of nineteenth-century liberalism, and they were indeed manifold. I do maintain, however, that questionable assumptions and serious gaps in this scholarly tradition cause it to tilt much too far in one direction.

For one thing, the broad question of Austrian liberalism's place in the history of modern liberalism as a whole merits closer attention and reconsideration. The comparative history of nineteenth and twentieth-century liberalism - if we except a few older intellectual histories such as that of Ruggiero - is not far advanced, for reasons which have already been outlined. The full history of how, precisely, Austrian liberalism resembled or differed from movements in Britain, France, the United States, etc., is an ambitious future project which must await further monographic research in the various regional fields. The recent flurry of interest among scholars of Britain in turn-of-the-century British neoliberalism provides an important example of the possibilities which can open up in an area of study which has long been considered exhausted. ${ }^{16}$

15. On Wandruszka, see footnote 4; Hans Rosenberg, "Political and Social Consequences of the Great Depression of 1873-1896 in Central Europe," The Economic History Review, 13 (1943): 58-73; Grosse Depression und Bismarckzeit: Wirtschaftsablauf, Gesellschaft und Politik in Mitteleuropa (Berlin, 1967).

16. E.g., Michael Freeden, The New Liberalism: An Ideology of Reform (Oxford, 1978); Peter Clarke, Lancashire and the New Liberalism (Cambridge, 1971) and Liberals and Social Democrats (Cambridge, 19' $\rightarrow$ For further bibliography on recent scholarship regarding British neo-liberalism, see Geoff Eley, "James 
More to the immediate point is the matter of the comparative history of Austrian and north German liberalism. ${ }^{17}$ For understandable reasons, Gesamtdeutsch historiography has been out of fashion since 1945; this has meant, unfortunately, that developments in Germany have usually been treated in unwarranted isolation from those of Austria-Hungary. This seems curious in light of the fact that virtually every leading student of modern central Europe pays lip service to the importance of an appreciation of regional variation in understanding the area's history. Were this view taken completely seriously, it would seem as important to integrate the stories of the Viennese, Lower and Upper Austrian, and Bohemian varieties of German liberalism into the general picture, as it would to include those of Baden, Saxony, Bavaria, etc. When the problem is approached from a central

Sheehan and the German Liberals: A Critical Appreciation," Central European History 14 (September 1981): 273-288, n. 7.

17. Perhaps the recent anthology edited by Robert A. Kann and Friedrich E. Prinz, Deutschland und Österreich: Ein bilaterales Geschichtsbuch (Vienna, 1980), will encourage further interest in a comparative approach to the history of Germany and Austria. In his article "What is German History? Reflections on the Role of the Nation in German History and Historiography," The Journal of Modern History, 53 (1981): 1-24, Sheehan has also called for a broader, comparative perspective in historical studies of modern German Europe. During the 1970s there was a significant revival of interest in liberalism in Wilhelmine Germany, mainly with respect to its relationship to social conservatism, imperialism, and the notion of a German Sonderweg, or "special course," to modernity. See the very useful Bibliographie zum deutschen Liberalismus (Göttingen, 1981), edited with an interesting forward by Jürgen C. Hess and E. van Steensel van der Aa. More specifically, in addition to Sheehan's study of German Liberalism and the essays edited by Holl and List, cited above, $\rightarrow$ Thomas Nipperdey, "Wehlers 'Kaiserreich.' Eine kritische Auseinandersetzung," Geschichte und Gesellschaft, 1 (1975): 539-560;

$\rightarrow$ Hans-Günter Zmarzlik, "Das Kaiserreich in neuer Sicht?" Historische Zeitschrift, 222 (1976): 105-1 $\rightarrow$ Wolfgang J. Mommsen, "Der deutsche Liberalismus zwischen 'klassenloser Bürgergesellschaft' und 'Organisertem Kapitalismus'. Zu einigen neueren Liberalismusinterpretationen," Geschichte und Gesellschaft, 4 (1978): 7790; al $\rightarrow$ Lothar Gall, "Der deutsche Liberalismus zwischen Revolution und Reischsgründung," Historische Zeitschrift, 228 (1979): 98-108. Also relevant are Eley's very perceptive "James Sheehan and the German Liberals, "cited above, and the review article by Konrad H. Jarausch, "Illiberalism and Beyond: German History in Search of a Paradigm," The Journal of Modern History, 55 (June 1983): 268-284. A central issue in much of this literature, dominated by a spirit of political sociology inspired by Marx and Weber and keyed to modernization theory and Walt Rostow's "take-off" thesis, is whether to situate the beginning of liberalism's "crisis" in the 1850 s or the $1880 \mathrm{~s}$. John W. Boyer's new study of Political Radicalism in Late Imperial Vienna represents one of the first efforts to develop an interpretation of late nineteenth-century Austrian politics informed by an acquaintance with the concepts and assumptions of the current historiography of Bismarckian and Wilhemine Germany. 
European point of view, one notes a wide range of assumptions, issues, and motifs which are common to the historiography of north German and German-Austrian liberalism, parallels which may have been alluded to impressionistically but which have rarely been studied in systematic fashion: the idea, for example, of liberalism's "failure" in 1848 - a genuine cliché which few bother to question; the chronic condition of Vereinsmeierei, or "clubishness," which hindered the development of party discipline; the notion that liberals squandered their energies in obsessive campaigns against the Catholic Church in the 1860s and 1870s; the idea that later challenges to liberalism by Christian Socialism and social democracy led to the development of a defensive "seige mentality" and a "hardening of attitudes" among liberals. All of these thematic parallels - and others, as well - deserve systematic, comparative investigation. The differences brought to light by this kind of scrutiny will naturally be just as instructive as the similarities.

Also within the comparative context, it would be wise to pay more attention to the native eighteenth and early nineteenthcentury sources of central European liberalism. In Austria's case, there is already a swelling literature on Joseph II and the "Josephinian" tradition which amply illustrates the ambiguous relationship between enlightened Hofratsliberalismus on the one hand - with its ideal of the well-tempered bureaucratic Rechtsstaat - and liberal individualism and mistrust of the state on the other. But this emphasis on Josephinism, important as it is, has encouraged neglect of the relationships between Weimar classicism, north German philosophy, and liberalism in Austria. Despite the strength of Josephinism, and despite all the efforts of the Church and the Habsburg restoration to quarantine the monarchy from northern influences, north German ideas were widely known, discussed, and assimilated by the Austro-German intelligentsia and administrative elite in the Vormärz. ${ }^{18}$ The public and private discourse of German-Austria - its correspondence, diaries, imaginative literature, historiography, political rhetoric, etc., - testifies to the fact that Austrian intellectuals and liberal politicians worked in essentially the same metaphorical framework and with the same eighteenth-century themes as their north German counterparts - Bildung, maturation, spiritual freedom, etc. The methods of comparative literary criticism and the social

18. David S. Luft, Robert Musil and the Crisis of European Culture, 1800-1942 (Berkeley, 1980), p. 7. 
history of ideas could be profitably applied to the further exploration of these relationships.

A special problem in this regard is presented by the conventional notion that the Aufklärung's introspective approach to freedom - the cult of Bildung associated with the Weimar circle and Kant - actually constituted a key obstacle to the growth of an activist, democratic-liberalism in German Europe and provided a convenient smoke-screen for the elitism of Bildung und Besitz. ${ }^{19}$ There is much truth in this, and it is not difficult to find Austrian cases which fit the pattern; Stifter's famous novel Der Nachsommer, for example, has often been read as an archetypical case of the approach to freedom as a passive escape or refuge, rather than an activist answer to pressing political and social problems. Yet one should be wary of dismissing the Bildung tradition out of hand, as automatically conducive to political timidity, quietism, or ivory tower withdrawal; the eighteenth-century German approach to liberty may not have been quite as inherently inimical to democratic activism as it is normally made out to be. Classical Marxism, for example - in its ideas of class consciousness and proletarian revolution - builds directly on the Bildung tradition of freedom; the same can be said of revisionist socialism. Moreover, most central European democrats - from those of 1848 down to Dahrendorf - have drawn powerful inspiration from the eighteenth-century tradition. Finally, we should not dismiss outof-hand the importance of the "self-help" approaches associated with early reform liberalism in the 1850 s, 1860 s, and 1870 s, which were inspired in central Europe largely by the idea of Bildung. It should not be forgotten that the "self-help" approach - based on the idea of the assimilation of laboring groups to the existing social and economic system - conformed to the actual historical experience of most liberal leaders. The pattern had always been for the talented and ambitious to assimilate to the German elite, and this understandably shaped the expectations of early reformers. ${ }^{20}$ At the turn of the century, revisionist socialism and reform liberalism - both largely inspired by the eighteenth-century tradition - showed faint but encouraging signs of merging into a democratic, progressive activism.

Finally, a comparative approach would highlight important rhetorical and conceptual problems related to the historiography of central European liberalism. The entire issue of the terminology

19. See, e.g., Sheehan, German Liberalism, pp. 18, 104.

20. On the wisdom of an old-fashioned "historist" perspective in such matters, see Nipperdey, “Wehler's Kaiserreich'," p. 545. 
used to interpret liberalism, for example, could profit from more conscious reflection. The terms and metaphors which control present-day discourse about nineteenth-century liberalism are, to a great extent, taken over directly from the figurative language of pathology invented in some cases, and broadcast by insecure or disillusioned turn-of-the-century liberals themselves (as well as by renegade progressives whose original liberalism had curdled and gone sour). Aside from the very limited use of more sophisticated statistical and quantitative methods, contemporary students of liberalism have not gone much beyond the left-liberal vocabulary of scholarship and journalism associated with such figures as Max Weber and Friedrich Naumann in Germany, Heinrich Friedjung, Richard Charmatz, and Friedrich Hertz in Austria - men who disseminated a language of analysis for the pre-1914 generation. The key images and phrases used to explain liberalism today - e. g., "paralysis," "decline," "myopia," "bankruptcy," and perhaps the most threadbare of the lot, "crisis" - are basically the ones introduced before the Great War. ${ }^{21}$ Obviously, historians cannot ignore the imagery and texture of the language used by people they study; in the case of liberalism (traditionally associated with selfexamination and toleration of heretical viewpoints), turn-of-thecentury liberals were themselves among their own best critics. Still, whatever advantages the historian enjoys over the subjects of his study he owes largely to refinements of vocabulary, diction, and syntax made possible by hindsight. The fact is that historians of central Europe have been unimaginative in searching for a fresh linguistic framework of analysis to explain nineteenth-century liberalism, and often have not been very thoughtful in using the language they have inherited.

Closely associated with the problem of terminology is the question of periodization. I have already alluded to the obvious but nonetheless frequently ignored pitfalls of mechanically dividing "periods" into "early," "high," and "late" phases of development, a practice inspired by the analogy of the life cycle with its stages of "growth" and "decadence." Despite the current fashion of emphasizing "continuity" in central European studies, for explanatory purposes most historians continue to rely heavily on the practice of packing time into descrete "eras" or "epochs." There is genuine irony in the fact that historians of Austria - in stark

21. These are all taken from Sheehan's German Liberalism, pp. 118, 273, 154, 283, 140. Compare the imagery, for example, of Charmatz's "Die Deutschfortschrittlichen," Der Weg (Vienna), 7 October, 1905. 
contrast to the slight long-range importance they generally attribute to liberalism - often refer to the 1860 s and 1870 s, or even to the entire period between 1867 and 1918 , as die liberale $\ddot{A}$ ra or das liberale Zeitalter. ${ }^{22}$ This well-worn convention is a legacy of Friedjung's generation. In Austrian history, the financial crash of 1873 is typically depicted as a symbolic event which sounded the death knell of the "liberal era." Unquestionably, liberalism as a political creed lost much of its élan after the 1870s. Nevertheless, the practice of conceptualizing events in terms of self-contained "epochs" is fraught with danger, especially insofar as it can serve as a way to quietly suggest that past approaches to problems are "transcended" by "history" and lose all relevance for the future.

In the space remaining I wish to draw attention to three important but neglected areas of study: biography, the relationship of political and intellectual history to economic history, and the subject of progressive (or "neo") liberalism.

Perhaps most striking of all in this connection is the slight attention paid to biographical research on Austrian liberals, either as individuals or as a group. Broad generalizations about "liberalism" and the group psychology and behavior of "the liberals"abound, but we really know remarkably little in detail about individual liberals - their life histories, personalities, and unique sensibilities. Even in Austria it is difficult to find recent biographical studies. In some instances this situation may be attributed to a lack of documentation, but in many cases it simply reflects the fact that archives and libraries have not been combed with a view to liberal biography.

In the late 1970s, for example, the Austrian National Library's subject catalog for the period since 1931 listed one article reprint on the federalist Adolf Fischhof, one dissertation each on the editor Moritz Benedikt, the parliamentary leader Eduard Herbst, and the historian Richard Charmatz, one article reprint on Joseph Redlich, and nothing at all on Ernst von Plener. The case of so well-known a figure as Anton von Schmerling is especially interesting. Schmerling's Nachlass has been housed in the Austrian state archives since the late 1930s, yet so far as I can determine it has been the basis for only one 59-page biographical essay by Paul Molisch ${ }^{23}$

22. E.g., Erich Zöllner, Geschichte Österreichs von den Anfängen bis zur Gegenwart, 4th ed. (Vienna, 1970), p. 413; Fuchs, Geistige Strömungen, p.5. On the origins of this convention, see Walther, "Exkurs: Wirtschaftlicher Liberalismus," pp.808-809.

23. Paul Molisch, Anton von Schmerling und der Liberalismus in Österreich (Brünn, 1944). 
and four dissertations on special aspects of Schmerling's career despite the fact that it contains Schmerling's correspondence with his mother during 1848 and a lengthy draft of an autobiography in Schmerling's own hand.

Various reasons could be cited to explain the neglect of liberal biography. First, under the influence of social science methodology (and often with good reason) the research interests of historians in general have shifted way from biography narrowly conceived as "life history." Moreover, the liberal movement - despite the fact that it was led by intensely individualistic Honoratioren produced no magnetic leaders who captured the popular or scholarly imagination. One author has aptly observed that, aside from some impressive tombstones and two statues honoring Mayor Andreas Zelinka and the geologist Eduard Suess, there are no public monuments dedicated to liberals in Vienna. ${ }^{24} \mathrm{It}$ is true that many of the liberal leaders - e.g., Schmerling, Herbst, the younger Plener - strike one as cold, stiff, tactless, and unimaginative. Furthermore, after the eruption of popular anti-Semitism in the 1880 s, liberalism was increasingly identified as a "Jewish" ideology. This was of enormous significance, not only for the fortunes of liberalism as a political movement (culminating in the miserable showing of the "Bürgerlich-Demokratische Partei" in 1919), but for historiography of liberalism as well.

The problem can be resolved only through archival research. This work can be approached in various ways, and I will only make two suggestions in this regard. First, historians should try to investigate more closely not only the lives and careers of the liberals of Vienna, but those of other regions and cities as well: Linz, Graz, Brünn, Prague, etc. In the provincial cities, liberals frequently exercised political power longer than in the imperial capital, sometimes right to the end of the Habsburg period; more attention to the local history of liberalism would enrich and counterbalance the traditional, one-sided focus on Austro-German liberalism as an essentially Viennese phenomenon. ${ }^{25}$

Secondly, Namierite and sociological approaches which aim at

24. Vocelka, Verfassung oder Konkordat?, p. 134.

25. A scattering of relevant local studies does exist: William H. Hubbard, "Politics and Society in the Central European City: Graz, Austria, 1861-1918," Canadian Journal of History, 5 (March 1970): 25-45; Kurt.Wimmer, Liberalismus in Oberösterreich (Linz, 1979); Kurt Tweraser, "Der Linzer Gemeinderat 1880-1914: Glanz und Elend bürgerlicher Herrschaft," Historisches Jahrbuch der Stadt Linz (1979): 293-341; and, most recently, Gary B. Cohen, The Politics of Ethnic Survival: Germans in Prague, 1861-1914 (Princeton, N.J., 1981). 
the collective political or social biography of liberals (though these would, in themselves, be exceedingly valuable) are unlikely to yield results which would cause us to question conventional generalizations, or go beyond the tedious ideological "unmasking" and tendentious linking of liberalism with "bourgeois culture" which is already so common. It is a fact that, politically, the mid and late-nineteenth century liberals fell dramatically from grace and that, socially, their mainstream views were overwhelmed by new, more populist and democratic attitudes. Few would disagree that "By the turn of the century, liberalism had been pushed to the fringes of the political scene, seriously weakened by its own divisions and ambiguities," although whether one can speak of its "apparently irreversible alienation from the most active forces in German life" 26 is less clear. A broader appreciation of the significance of liberalism in nineteenth-century life requires an understanding of its individual nuances and anomalies, and this suggests that the current methodological orthodoxy of political sociology, with its emphasis on the "class" character of liberal "ideology," should be complemented whenever possible by other methods, such as those of traditional intellectual history combined with newer techniques of rhetorical and stylistic criticism. Austrian archives and libraries are rich in unexploited collections of correspondence, unpublished memoirs, diaries, etc. A close reading of these private texts (along, of course, with published works), one concerned with the private and public rhetoric of liberalism - its texture, surface imagery, and metaphorical structure - offers a promising method for constructing the mental biography of liberalism, fixing the place of the liberal sensibility and imagination in late Habsburg history, and for helping to determine its meaning for future generations as well.

A different but potentially equally rewarding field of inquiry concerns the question of relationships between Austrian economic growth, economic theory, and liberalism. Until quite recently, the entire field of modern Austro-Hungarian economic history was itself virtually "dormant." 27 Traditionally, scholarly interest was trained on the more dramatic cases of industrialization or economic backwardness - Britain, America, and Bismarckian Germany on the one hand, tsarist Russia on the other - and historians of the

$2 \rightarrow$ James J. Sheehan, "Liberalism and the City in Nineteenth-Century Germany," Past and Present, 51 (May 1971): 116.

27. N.T. Gross, The Industrial Revolution in the Habsburg Monarchy, 1750-1914 (London, 1972), p. 12 (reprinted from Carlo M. Cipolla, ed., The Fontana Economic History of Europe, vol. 4: pp. 228-278). 
Austrian economy were largely content to adapt their data to general theoretical frameworks, particularly the widely held notion of a "great depression" in Europe between 1873 and $1896 .{ }^{28}$ The key event in this cataclysmic configuration of events is the Vienna stock market crash of 1873. In Austrian historiography, the great $\mathrm{Krach}$ carries a heavy load of symbolism; almost universally, it is represented as having shaken "middle-class society" - and its liberal political leadership - to the roots, and it is conventionally used as a device to signify the onset of liberalism's demise.

The practice of unreflectively invoking the "great depression" thesis as a ready-made device for explaining liberalism's "decline" has become so commonplace as to arouse a certain measure of skepticism. What if there were no "great depression?" In the case of Britain, it has in fact been argued that the idea is a myth, ${ }^{29}$ and Alexander Gerschenkron has called the idea "dubious" for Germany as well..$^{30}$ Recently, an alternative school of thought in Austrian economic history - "analytical" as opposed to "descriptive" - has arisen. The approach rests on often controversial quantitative methods and its adherents warn that their findings are tentative. ${ }^{31}$ Nevertheless, they have seriously challenged the notion that nineteenth-century Habsburg economic development was essentially characterized by dramatic booms and busts, and some have specifically questioned the idea of a "great depression" in Austria. One scholar states flatly: "Austria does not seem to have suffered a long depression in the 23 years after the crash of $1873 . .$. in terms of the behavior of real output, the 'great depression' in Austria, as in England, is essentially a myth." 32

What are the implications of this position for our understanding

28. For central Europe, Hans Rosenberg has been the most important popularizer of the "great depression" thesis: see note 13.

29. S.B. Saul, The Myth of the Great Depression, 1873-1896 (London, 1969).

30. "The Great Depression in Germany," in Alexander Gerschenkron, Continuity in History and Other Essays (Cambridge, Mass., 1968), p. 406

31. For a bibliography of the recent work, as well as some of the more important older studies, see Richard L. Rudolph, Banking and Industrialization in AustriaHungary: The Role of Banks in the Industrialization of the Czech Crownlands, 18731914 (Cambridge, 1976), p. 233, n. 3. Österreichische Akademie der Wissenschaften, Die Habsburgermonarchie 1848-1918, 1: Die wirtschaftliche Entwicklung (Vienna, 1973) presents both traditional and more recent points of view.

32. David F. Good, "Stagnation and 'Take-Off' in Austria, 1873-1913," The Economic History Review, second series, 27 (1974): 83. See also chapters one (on Germany) and five (on Austria-Hungary) of Alan S. Milward and S.B. Saul, The Development of the Economies of Continental Europe, 1850-1914 (Cambridge, Mass., 1977); also Nipperdey, "Wehler's 'Kaiserreich'," p. 556, who notes a tendency for the "great depression" thesis to become a fast allerklärenden Mythos. 
of Austrian liberalism and, indeed, for our general attitudes toward late nineteenth-century Austrian political history as a whole? This is a complex problem which requires careful research and reflection. Even if the econometric thesis proves ultimately convincing, we cannot overlook the fact that market fluctuations, financial scandals, etc., were widely perceived in a traumatic way, and that this perception contributed to disillusionment with liberalism and a climate of cynicism or indifference toward rational politics in general; the testimony of the contemporary press, periodicals, pamphlet literature, and private papers is simply undeniable on this score. On the other hand, it may be that one of the reasons for the popularity of the "great depression" theory is that it has served so well the students of "cultural despair" and antiSemitism who are really interested in the roots of National Socialism, and not primarily in the late nineteenth century itself. Moreover, in recent years the influence of Marxian theory has been so pervasive that even the most superficial accounts of the "decline and fall" of the old order in central Europe have at least had to bow melodramatically in the direction of economic "crisis." It may prove that this has led to an exaggerated emphasis on the weakness of liberalism as an idea, if not as a political movement, in the late nineteenth century.

One suspects that the "great depression" paradigm is to some extent a backward projection of the personal experience of its disseminators during the "great depression" of the 1930s, which is also regularly explained as a "crisis" of liberalism. Coincidentally, in both the 1870s and the 1930s the onset of "crisis" was signaled by a Viennese crash. Rosenberg, it should be noted, displays a propensity for finding "great depressions" in the German past - as far back as the early seventeenth century. ${ }^{33}$

Beyond this is an area of Austrian economic and intellectual history which is especially noteworthy for the lack of interest it has aroused among historians: the "Austrian School" of economic theory associated with Carl Menger, Friedrich von Wieser, and Eugen von Böhm-Bawerk, and its specific relationship to the late nineteenth-century context. Though its doctrines were influential and widely debated in the first three decades of this century, careful study of this school - with its emphasis on the heroic role of the individual entrepreneur - has had very low marginal utility for the majority of scholars since the 1930s. Friedrich von Hayek's

33. See Hans Rosenberg, Bureaucracy, Aristocracy, and Autocracy: The Prussian Experience, 1660-1815 (1958; reprint ed., Boston, 1966), pp. 33, 59. 
roots in this tradition are, of course, acknowledged, and there is a cult of "free enterprisers" and libertarians in the United States who are enthusiasts for the doctrines of Menger, Böhm-Bawerk, and especially Ludwig von Mises. Even they, however, have not done much to shed light on the historical origins and significance of the doctrine - partly because the father of the school, Menger himself, disdained "historicism," partly due to their own lack of interest in historical explanation. In Austria itself, the current cimate of neoliberal/social democratic opinion has not been conducive to historical interest in Menger's ideas. ${ }^{34}$

Here, indeed, is a virtual historiographical vacuum. How, specifically, are the school's idea of marginal utility, its deductive, Aristotelian method, its opposition to "historicism," its theory of the business cycle, and its generally subjectivist approach to life related to the broader Austrian scene? Once again, basic intellectual biography would seem to be a logical first step. A concerted attempt should be made to relate the lives and ideas of the Austrian masters, and their lesser disciples such as Philoppovich, to the currents of late nineteenth-century political and cultural life: "classical" liberalism, as well as progressive neoliberalism and revisionist social democracy; generational conflict; the sense of undirected flux which preoccupied the Germanspeaking intelligentsia; upper-middle class aestheticism and status envy for the aristocracy; status anxiety vis-a-vis the masses; the intelligentsia's melancholy, adolescent obsession with the theme of arrested growth; the fashionable rhetoric of decline and the iconography of threatened masculinity which surfaced so often in literature and the fine arts, and which permeates private records as well. ${ }^{35}$

34. See the remarks of F.A. Hayek, "The Place of Menger's Grundsätze in the History of Economic Thought," in J.R. Hicks and W. Weber, eds., Carl Menger and the Austrian School of Economics (Oxford, 1973), pp. 4-5. Also Murray N. Rothbard, "New Light on the Prehistory of the Austrian School," in Edwin G. Dolan, ed., The Foundations of Modern Austrian Economics (Kansas City, 1976), pp. 52-74; Emil Kauder, A History of Marginal Utility Theory (Princeton, N.J., 1965) and "Intellectual and Political Roots of the Older Austrian School," Zeitschrift für Nationalökonomie, 17 (December 1957): 411-425. For general bibliography, see Hayek's article on the "Austrian School" in the International Encyclopedia of Social Sciences and the references in Wiliam M. Johnston's The Austrian Mind (Berkeley, 1973) and R.S. Howey's The Rise of the Marginal Utility School, 1870-1889 (Lawrence, Kansas, 1960).

35. For some sketchy, impressionistic thoughts along these lines, see Erich Streissler, "Structural Economic Thought: On The Significance of the Austrian School Today," Zeitschrift für Nationalökonomie, 29 (December 1969): 237-266, especially pp. 256-260. 
Finally, I would like to draw attention to one last topic which has been traditionally overlooked: progressivism, or "neoliberalism" (Neuliberalismus). In their rush to dispense with liberalism and advance to the subjects of political extremism, irrationalism, and expressionism, historians of central Europe have tended to reduce turn-of-the-century liberalism to an autumnal Geisteshaltung of melancholy Kulturliberalismus, or, at best, to represent it as a derivative "post-liberal" echo of an allegedly alien west European reformism. They seem to have been willing to agree with Mussolini that liberalism was "no more than a parenthesis" in central European history. ${ }^{36}$ This point of view may have appeared compelling in the 1930s and 1940s, when fascism and communism seemed to many people to provide the chief political and economic alternatives of the twentieth century. It should seem less convincing today, however, at a time when revisionist liberalism is the working philosophy of the west European and North American welfare state, all intellectually chic references to the "bankruptcy" of liberalism notwithstanding. Much of the confusion results from the simple fact that all too often the authors of liberalism's obituary are really talking about the "classical liberalism" of a generation of liberals - usually that of the 1860s and 1870s - and not about the evolving and continuing tradition of liberalism itself. Speaking of the situation in Britain, where similar problems of interpretation exist, one scholar has noted:

Modern liberalism has suffered mainly through sheer ignorance of its nature. Even now, many of its modern opponents assail with venom a set of principles that liberalism itself discarded almost a century ago.... the underestimation of liberalism appears to be the result of equating it with the Liberal party, of an aversion to considering ideology outside the aegis of party, and of a fixation with the mid-century liberalism of the utilitarians. . . condemning liberalism by relating it to its earlier prototype was a crude method of antiliberal propaganda used by its opponents at the turn of the century, but later transformed into a myth not refuted by scholarship. ${ }^{37}$

36. Benito Mussolini, "The Doctrine of Fascism," in John Louis Beatty and Oliver A. Johnson, eds., Heritage of Western Civilization, 4th ed. (Englewood Cliffs, N.J., 1977), vol 2: p. 337.

37. Michael Freeden, The New Liberalism, pp. 1, 255. As for the association of laissez-faire economics and liberalism, Freeden argues (p. 23) that this was "transient." Freeden's discussion of the essential and ephemeral elements of the British liberal tradition on pp. 22-23 might well be extended to the western liberal tradition as a whole. 
At present, it seems reasonable to entertain the idea that pre1914 revisionist liberalism in Austria - like progressive liberalism elsewhere - represents a prelude rather than a climax, a glimmer of the neo-liberal/social democratic future rather than a quixotic effort to resuscitate the corpse of a dead ideology. At the very least, progressivism deserves to be rescued from posterity's condescension and recognized as an important undercurrent in the intellectual and political history of Austria on the eve of World War I. ${ }^{38}$

This viewpoint is, in fact, beginning to win modest support. Such recent books as Ingrid Belke's study of Josef Popper, ${ }^{39}$ and especially Eva Holleis' brief survey of Viennese Fabianism and the Sozialpolitsche Partei, ${ }^{40}$ highlight turn-of-the-century efforts to revise liberal doctrine to meet the demands of industrial society and democratic politics, and suggest that neo-liberal projects may have been something more than "poignant examples of hope's triumph over experience" in central Europe.41

Actually, one suspects that Austrian liberalism - even in its "classical" and "national liberal" guises - was never quite so rigid or socially obtuse as it is regularly made out to have been. Karl Giskra's infamous remark about the social question stopping "at Bodenbach" was perhaps more exceptional in its callousness than genuinely representative of liberal opinion. Heinrich Friedjung, the famous historian, is a good example of a liberal who is seldom associated with enlightened social views. In point of fact, Friedjung was a perceptive sociocultural historian, as the second volume of his unfinished Österreich von 1848 bis 1860 testifies. He began his political career as a populist and, as editor of the Deutsche

38. One of the few American studies to address the subject in Austria, even in passing, is John W. Boyer, "Freud, Marriage, and Late Viennese Liberalism: A Commentary from 1905," The Journal of Modern History, 50 (March 1978): 72-102, especially pp. 73-91. It, too, views progressivism in terms of "post-liberal bourgeois culture" (p.77). Boyer's reference to "the destruction of [Vienna's] German Liberal tradition" by 1895 (Political Radicalism in Late Imperial Vienna, p. ix), is only justified in party political terms.

39. Ingrid Belke, Die sozialreformischen Ideen von Josef Popper-Lynkeus (1838-1921) in Zusammenhang mit allgemeinen Reformbestrebungen des Wiener Bürgertums um die Jahrhundertwende (Tübingen, 1979).

40. Eva Holleis, Die Sozialpolitische Partei: Sozialliberale Bestrebungen in Wien um die Jahhundertwende (Munich, 1978).

41. Sheehan, German Liberalism, p. 258. American critics have not thus far been impressed by the possible merits of this approach. See the unenthusiastic review of Holleis by William H. Hubbard, The American Historical Review, 85 (December 1979): 1421-1422. 
Wochenschrift in the 1880s, he consistently devoted a large amount of space to social issues. As a liberal city councilor in Vienna in the early 1890 s, he defended social reform, and was a member of the Viennese Fabian Society.

Other examples could be cited, such as the efforts of Richard Charmatz and the circle around the short-lived periodical Der Weg to encourage industrialization and foster a "neo-liberal" political alliance of progressives and revisionist social democrats. ${ }^{42}$ Such efforts, it is true, enjoyed at best modest political success; in quantitative terms - the hard facts and figures and calculated "results" at the political ledger's "bottom line" - their practical achievements before 1914 do not amount to a great deal. In terms of the history of ideas and human sentiment, however, they are not unimportant. Moreover, Holleis has correctly assessed their longterm political significance for the twentieth century:

In the more distant future, the ideas and methods of the Sozialpolitiker proved themselves - at least in the western world - politically more effective than the Marxist, Christian, or nationalist ideologies. The fact is often overlooked that the social welfare state established in the west after 1945 rests on the theory and practice of liberal economists who have worked since the 1870 s....

Whoever looks for the roots of the Austrian welfare state will inevitably encounter the social-political movement at the end of the nineteenth century. The ideas of the Sozialpolitiker, their notions of a liberal welfare state, have been realized today in almost all the states of the western world..$^{43}$

In conclusion, there may indeed be genuinely sound reasons for contriving the history of late nineteenth-century Austrian liberalism in ironic terms: the existence of a tension, for example, between the oft-encountered liberal emphasis on "manliness" as an expression of independence and self-reliance, and many individual liberals' characteristic self-pity and debilitating sense of inferiority in the face of an ideal of baroque aristocratic grace which the liberal imagination itself had done much to invent. The notion of the "death" of liberalism at the turn-of-the-century, however, is

42. Charmatz, Deutsch-Österreichische Politik, pp. 7-9, 239, 305-306, 308, 324. A broad range of other examples can be found in Belke, Die sozialreformischen Ideen.

43. Holleis, Die Sozialpolitische Partei, pp. 107, 112. Freeden's remarks concerning Britain in The New Liberalism, p. 1, are similar in tone. For Germany, cf. Zmarzlik, "Das Kaiserreich in neuer Sicht?" pp. 69-70; also Nipperdey, "Wehler's 'Kaiserreich',' pp. 543-545, 554-555. 
not one of them. In this respect, it perhaps is often not so much the liberals themselves as some of their historians who should be viewed ironically. If, after having reconsidered the subject of late nineteenth-century Austrian liberalism, it proves impossible to imagine its history in the reconciliatory terms of high comedy, it may at least be possible to avoid the teleological clichés of specious "tragedy," the pathos of middlebrow journalism, and the conceit of glib irony. 